\title{
Pengaruh Tekanan Keuangan Dan Kapitalisasi Pasar Terhadap Nilai Pasar Perusahaan Transportasi Di Indonesia
}

\author{
Deni Sunaryo ${ }^{1}$, Abdul Fatah ${ }^{2}$, Abdul Malik ${ }^{3}$ \\ 1,2,3Program Studi Manajemen, Fakultas Ekonomi dan Bisnis, Universitas Serang Raya, Banten, \\ Indonesia \\ Email: 1*denisunaryomm@gmail.com, 2abfatah204@gmail.com, \\ 3abdulmalik.unsera@yahoo.com
}

\begin{abstract}
Objective This study aims to determine the Effect of Financial Pressure and Market Capitalization on the Market Value of Companies in the transportation. The population used in this study is the transportation sub-sector companies listed on the Indonesia Stock Exchange (BEI) from 2013 to 2018. The sampling technique used was purposive sampling method and obtained 10 companies. The data collected is secondary data with the documentation method through www. idx.com is the company's annual report. The analytical tool used to test hypotheses is SPSS23. The results of this study are (1) Financial Pressure has a significant effect on the Company's Market Value, (2) Market Capitalization has no effect on the Company's Market Value
\end{abstract}

Keywords: Company Market Value, Financial Pressure and Market Capitalization

\begin{abstract}
Abstrak
Tujuan Penelitian ini bertujuan untuk mengetahui Pengaruh Tekanan Keuangan dan Kapitalisasi Pasar terhadap Nilai Pasar Perusahaan sub sektor transportasi. Populasi yang digunakan dalam penelitian ini adalah perusahaan sub sektor transportasi yang terdaftar di Bursa Efek Indonesia (BEI) periode 2013 - 2018. Teknik pengambilan sampel yang digunakan adalah metode purposive sampling dan diperoleh 10 perusahaan. Data yang dikumpulkan merupakan data sekunder dengan metode dokumentasi melalui www.idx.com berupa annual report perusahaan. Alat analisis yang digunakan untuk pengujian hipotesis adalah SPSS23. Hasil dari penelitian ini adalah (1) Tekanan Keuangan berpengaruh signifikan terhadap Nilai Pasar Perusahaan (2) Kapitalisasi Pasar tidak berpengaruh terhadap Nilai Pasar Perusahaan.
\end{abstract}

Kata Kunci: Nilai Pasar Perusahaan, Tekanan Keuangan, Kapitalisasi Pasar

\section{PENDAHULUAN}

Transportasi merupakan hal sangat penting bagi perkembangan suatu bangsa. Dimana perusahaan jasa yang terdaftar di Bursa Efek Indonesia (BEI) terdiri dari 4 sektor, yaitu: sektor property dan real estate: sektor infrastruktur, utilitas dan transportasi: sektor keuangan dan sektor perdagangan: jasa dan investasi. Sektor transportasi merupakan kunci yang akan mempengaruhi sektor manufaktur secara langsung, dan infrastruktur adalah salah satu faktor yang memperlancar perekonomian bangsa dimana meningkatkan kemajuan suatu daerah karena dapat mempermudah dalam menghasilkan barang serta pendistribusiannya.

Investasi infrastruktur sering menjadi investasi yang padat modal dengan laju pemulihan investasi yang lambat dan berjangka panjang. Hal tersebut menarik investor untuk menanamkan modal sehingga sangat dibutuhkan keadaan transportasi yang baik dan infrastruktur merupakan salah satu faktor penentu pembangunan ekonomi yang sama pentingnya dengan faktor-faktor produksi lainnya seperti modal dan tenaga kerja. 
Tabel 1.1

Perkembangan Jumlah Transportasi Menurut Kepulauan Tahun 2013-2017

\begin{tabular}{|c|c|c|c|c|c|c|}
\hline Kepulauan & 2013 & 2014 & 2015 & 2016 & 2017 & $\begin{array}{c}\text { Per } \\
\text { Tahun } \\
\underset{(\%)}{(\%)}\end{array}$ \\
\hline Sumatera & 26.012 .352 & 27.561 .913 & 29.203 .673 & 31.102 .700 & 34.071 .726 & 6,98 \\
\hline Jawa & 53.353 .720 & 60.369 .373 & 64.732 .957 & 68.636 .532 & 72.983 .542 & 8,15 \\
\hline $\begin{array}{l}\text { Bali-Nusa } \\
\text { Tenggara }\end{array}$ & 6.895 .138 & 7.294 .341 & 7.467 .427 & 8.180 .258 & 8.790 .530 & 6,26 \\
\hline Kalimantan & 8.194 .335 & 8.784 .293 & 9.253 .331 & 9.825 .201 & 10.468 .288 & 6,31 \\
\hline Sulawesi & 8.292 .170 & 8.751 .748 & 9.217 .729 & 9.851 .461 & 10.271 .832 & 5,50 \\
\hline $\begin{array}{l}\text { Papua-Kep } \\
\text { Maluku }\end{array}$ & 1.371 .254 & 1.447 .592 & 1.510 .068 & 1.684 .927 & 1.970 .751 & 9,49 \\
\hline Jumlah/Total & 104.118 .969 & 114.209 .260 & 121.394 .185 & 129.281 .079 & 138.556 .669 & 7,40 \\
\hline
\end{tabular}

Pada Tabel 1.1 periode 2013-2017, terdapat peningkatan jumlah kendaraan yang cukup tinggi 7,40 persen unit per tahunnya. Peningkatan jumlah kendaraan pada semua jenis kendaraan setiap tahunnya juga mempunyai efek pembangunan infastruktrur yang terus berkembang. Realisasi investasi di sektor transportasi sepanjang 2017 telah mencapai Rp78,11 triliun atau tumbuh $10 \%$ secara tahunan. Pencapaian tersebut lebih baik dibandingkan dengan realisasi pada 2016 yang terkoreksi 16,98\%. Data Badan Koordinasi Penanaman Modal (BKPM) menunjukkan, realisasi investasi di investasi dalam negeri sebesar Rp35,78 triliun dan investasi asing sebanyak US\$3,17 miliar atau setara Rp42,33 triliun. Sebagai catatan, data yang dicuplik dari BKPM itu mencakup realisasi investasi di sektor transportasi, pergudangan, telekomunikasi, dan peralatan transportasi. Berdasarkan sumber aliran modal, realisasi investasi domestik di sektor transportasi sepanjang 2017 tumbuh $25,57 \%$ sedangkan investasi asing naik tipis $2,63 \%$. Kendati tumbuh di bawah $10 \%$, realisasi investasasi asing tercatat mengalami pemulihan karena sepanjang 2016 turun 38,79\%. Dalam sembilan bulan 2017, sektor transportasi dan pergudangan tumbuh $8,25 \%$. Nilai investasi pada sektor transportasi yang mengalami pertumbuhan bisa saja terjadi, karena memang perbaikan kinerja transportasi. Kebijakan itu terkait dengan peningkatan daya saing penyedia jasa logistik nasional. Berharap, sektor transportasi bakal terus mencetak pertumbuhan setiap tahunnya. Pertumbuhan investasi pada sektor transportasi juga akan memberikan keuntungan bagi sektor lainnya, salah satunya sektor pariwisata.

Diantara berbagai instrumen pasar modal, saham merupakan instrument investasi yang memiliki tingkat return dan risiko yang tinggi. Nilai transaksi atau yang dalam istilah pasar modal lebih dikenal sebagai nilai kapitalisasi yang tinggi yang mengindikasikan potensi perolehan laba yang tinggi. Disisi lain return atau investasi saham yaitu dividen dan capital gain lebih sulit diprediksi, sehingga investor harus melakukan analisis saham guna memperoleh keuntungan yang diharapkan.

Tinjauan dari penelitian tersebut adalah menyangkut Tekanan keuangan (Altman ZScore), Kapitalisasi pasar dan Current Ratio (CR). Adapun data yang diperoleh dari Bursa Efek Indonesia (BEI) berdasarkan nilai perusahaan adalah sebagai berikut: 
Tabel 1.2

Perusahaan Sub Sektor Transportasi yang Terdaftar di Bursa Efek Indonesia Periode 2013 -2018

\begin{tabular}{|l|c|c|l|}
\hline No. & Kode Saham & Nama Perusahaan & Tgl IPO \\
\hline 1 & RAJA & Rukun Raharja Tbk & 24 Des 1993 \\
\hline 2 & SMDR & Samudera Indonesia Tbk & 05 Des 1999 \\
\hline 3 & ASSA & Adi Sarana Armada Tbk & 12 Nov 2012 \\
\hline 4 & TMAS & Pelayaran Tempuran Emas Tbk & 9 Juli 2003 \\
\hline 5 & HITS & Humpus Intermoda Transportasi & 15 Des 1997 \\
\hline 6 & CASS & Cardig Aero Services Tbk & 05 Des 2011 \\
\hline 7 & NELY & Pelayaran Nely Dwi Putri Tbk & 11 Okt 2012 \\
\hline 8 & GIAA & Garuda Indonesia (Persero) Tbk & 11 Feb 2011 \\
\hline 9 & MIRA & Mitra International Resources Tbk & 30 Jan 1997 \\
\hline 10 & LEAD & Logindo Samuderamakmur Tbk & 11 Des 2013 \\
\hline
\end{tabular}

(Sumber: www.idx.co.id)

Tabel 1.2 berikut ini disajikan nama-nama perusahan yang diperoleh sebanyak 10 (sepuluh) dari 28 perusahaan sub sektor transportasi yang terdaftar di Bursa Efek Indonesia (BEl) pada periode 2013 - 2018. Transportasi adalah komponen utama dalam sistem hidup dan kehidupan dalam negara berkembang dan didukung dengan adanya kemajuan teknologi yang semakin canggih. Merupakan kondisi sosial demografis wilayah yang memiliki pengaruh terhadap kinerja transportasi di wilayah tersebut. Tingkat kepadatan penduduk mempunyai pengaruh signifikan terhadap kemampuan transportasi dalam melayani kebutuhan. Dengan analisis rasio ini kita dapat menunjukan beberapa hal.

Tabel 1.3

Altman Z-Score/ Tingkat Kebangkrutan Sub Sektor Transportasi yang Terdaftar di Bursa Efek Indonesia Periode 2013 -2018

\begin{tabular}{|c|c|c|c|c|c|c|c|}
\hline \multirow{2}{*}{$\begin{array}{c}\text { Kode } \\
\text { Saham }\end{array}$} & $\mathbf{2 0 1 3}$ & $\mathbf{2 0 1 4}$ & $\mathbf{2 0 1 5}$ & $\mathbf{2 0 1 6}$ & $\mathbf{2 0 1 7}$ & $\mathbf{2 0 1 8}$ & $\begin{array}{c}\text { Rata- } \\
\text { rata }\end{array}$ \\
\cline { 2 - 8 } \\
\hline RAJA & 0,001 & $-0,028$ & 0,049 & 0,070 & 0,070 & 0,173 & 0,056 \\
\hline SMDR & 0,014 & 0,028 & 0,031 & 0,025 & 0,018 & 0,042 & 0,026 \\
\hline ASSA & $-0,096$ & $-0,128$ & $-0,103$ & $-0,101$ & $-0,108$ & $-0,146$ & $-0,114$ \\
\hline TMAS & $-0,174$ & $-0,180$ & $-0,153$ & $-0,149$ & $-0,124$ & $-0,151$ & $-0,155$ \\
\hline HITS & $-0,020$ & $-0,029$ & $-0,017$ & $-0,084$ & 0,071 & 0,010 & $-0,012$ \\
\hline CASS & 0,183 & 0,218 & 0,260 & 0,364 & 0,344 & 0,109 & 0,246 \\
\hline NELY & 0,172 & 0,098 & 0,091 & 0,197 & 0,220 & 0,246 & 0,171 \\
\hline GIAA & $-0,056$ & $-0,132$ & $-0,696$ & $-0,107$ & $-0,248$ & $-0,250$ & $-0,248$ \\
\hline MIRA & 0,001 & 0,203 & 0,245 & 0,269 & 0,238 & 0,322 & 0,213 \\
\hline LEAD & $-0,079$ & $-0,053$ & 0,047 & 0,025 & 0,656 & $-0,047$ & 0,092 \\
\hline \multicolumn{7}{|c|}{ Tingkat Kebangkrutan pada sub sektor transportasi } \\
\hline
\end{tabular}

Sumber: Data yang diolah 2019

Pada tabel 1.3 dapat dilihat hasil daripenglafikasikan tekanan keuangan dengan menggunakan metode Altman Z-Score/ Tingkat kebangkrutan pada perusahaan Sub Sektor Transportasi yang terdaftar di BEI periode 2013-2018. Setelah diakumulasikan selama enam tahun dan kemudian dirata-ratakan, maka terlihat di tahun 2013 - 2018 perusahaan Rukun Raharja, Tbk sebesar 0,056, perusahaan Samudera Indonesia, Tbk sebesar 0,026, perusahaan Adi Sarana Armada, Tbk sebesar -0,114, perusahaan Pelayaran Tempuran Emas, Tbk sebesar $-0,155$, perusahaan Humpus Intermoda Transportasi, Tbk sebesar -0,012, perusahaaan Cardig Aero Service, Tbk 0,246, perusahaan Pelayaran Nely Dwi Putri, Tbk 0,171, perusahaan Garuda Indonesia (Persero) Tbk -0,248, perusahaan Mitra International Resources, Tbk sebesar 0,213 dan perusahaan Logindo Samuderamakmur Tbk sebesar 0,092. Selama enam tahun berturutturut mengalami fluktuatif. 
Tabel 1.4

Nilai Kapitalisasi Pasar Sub Sektor Transportasi yang Terdaftar di Bursa Efek Indonesia Periode $2013-2018$

\begin{tabular}{|c|r|}
\hline $\begin{array}{c}\text { Kode } \\
\text { Saham }\end{array}$ & Rata-rata tahun 2013-2018 \\
\hline RAJA & 1.368 .717 .750 .697 \\
\hline SMDR & 1.297 .707 .750 .687 \\
\hline ASSA & 1.244 .450 .250 .680 \\
\hline TMAS & 688.645 .808 \\
\hline HITS & 717.299 .566 \\
\hline CASS & 590.085 .113 .286 \\
\hline NELY & 493.563 .675 .740 \\
\hline GIAA & 396.520 .500 .694 \\
\hline MIRA & 396.520 .500 .694 \\
\hline LEAD & 1.398 .003 .539 \\
\hline
\end{tabular}

Sumber: Data yang diolah 2019

Pada tabel 1.4 dapat dilihat rata-rata Nilai kapitalisasi pasar pada perusahaan Sub Sektor Transportasi yang terdaftar di BEI periode 2013-2018.Di tahun 2013-2018 RAJA memiliki nilai rata-rata sebesar 1.368.717.750.697, SMDR memiliki rata-rata sebesar 1.297.707.750.687, ASSA memiliki nilai rata-rata sebesar 1.244.450.250.680,TMAS memiliki sebesar nilai rata-rata 688.645.808, HITS memiliki nilai rata-rata sebesar 717.299.566, CASS memiliki nilai rata-rata sebesar 590.085.113.286, NELY memiliki nilai rata-rata sebesar 493.563.675.740, GIAA memiliki nilai rata-rata sebesar 396.520.500.694, MIRA memiliki nilai rata-rata sebesar 396.520.500.694 dan LEAD memiliki nilai rata-rata sebesar 1.398.003.539. Dari tabel diatas dapat dilihat gambaran grafik nilai rata-rata dari tahun 2013-2018 seperti dibawah ini:

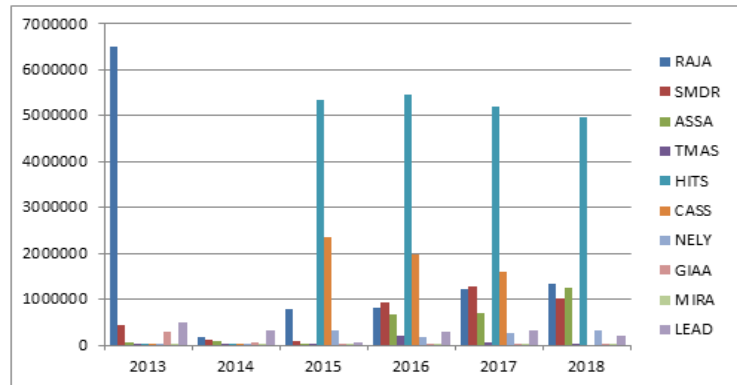

Sumber: Data diolah kembali

Gambar 1.1 Nilai Kapitalisasi Pasar

Dari gambar 1.1 grafik diatas bisa dilihat dari tahun 2013 perusahaan dengan kode saham RAJA memiliki nilai kapitalisasi pasar yang tinggi dibandingkan dengan perusahaanperusahaan transportasi lainnya ditahun 2013. Dan ditahun 2014 mengalami penurunan yang drastis dari tahun sebelumnya.Dan ditahun 2015 - 2018 perusahaan dengan kode saham HITS memilki nilai kapitalisasi pasar yang cukup stabil.Perusahaan lainnya memiliki nilai kapitalisasi yang fluktuatif.

Tabel 1.5

Current Ratio (CR) Sub Sektor Transportasi yang Terdaftar di Bursa Efek Indonesia Periode 2013 2018

\begin{tabular}{|c|c|c|c|c|c|c|c|}
\hline \multirow{2}{*}{$\begin{array}{l}\text { Kode } \\
\text { Saham }\end{array}$} & \multicolumn{6}{|c|}{ Nilai Satuan \% } & \multirow{2}{*}{$\begin{array}{c}\text { Rata- } \\
\text { Rata }\end{array}$} \\
\hline & 2013 & 2014 & 2015 & 2016 & 2017 & 2018 & \\
\hline RAJA & 4,63 & 2,84 & 8,9 & 6,44 & 5,58 & 6,29 & 5,78 \\
\hline SMDR & 3,77 & 3,75 & 3,65 & 3,5 & 3,38 & 3,1 & 3,525 \\
\hline ASSA & 5,29 & 4,66 & 4,7 & 5,07 & 4,49 & 3,73 & 4,65666 \\
\hline & 3,13 & 2,64 & 2,92 & 3,8 & 3,88 & 3,51 & 3,31333 \\
\hline HITS & 4,96 & 4,66 & 3,83 & 3,56 & 6,37 & 5,18 & 4,76 \\
\hline CASS & 2,9 & 3,07 & 3,01 & 3,38 & 3,4 & 2,88 & 3,10666 \\
\hline NELY & 7,57 & 8,3 & 8,85 & 17,91 & 15,65 & 18,51 & 12,7983 \\
\hline GIAA & 3 & 2,54 & 2,76 & 2,39 & 1,95 & 1,78 & 2,40333 \\
\hline MIRA & 7,36 & 6,52 & 6,8 & 6,2 & 5,98 & 11,44 & 7,38333 \\
\hline LEAD & 5,46 & 7,12 & 7,09 & 15,4 & 11,9 & 6,6 & 8,92833 \\
\hline
\end{tabular}


Pada tabel 1.5 dapat dilihat rata-rata Current Ratio dalam nilai (\%) pada perusahaan Sub Sektor Transportasi yang terdaftar di BEl periode 2013-2018.Di tahun 2013-2018 RAJA sebesar 5,78\%. SMDR di tahun 2013-2018 sebesar 3,525\%. Pada tahun 2013-2018 ASSA sebesar 4,65666\%. Di tahun 2013-2018 TMAS sebesar 3,31333. Dari tahun 2013-2018 HITS sebesar 4,76\%. Di tahun 2013-2018 CASS sebesar 3,10666\%. NELY dari tahun 2013-2018 sebesar $12,7983 \%$. GIAA ditahun 2013-2018 sebesar 2,40333\%. Di tahun 2013-2015 MIRA sebesar 7,38333\% dan LEAD ditahun 2013-2018 sebesar 8,92833\%.

Nilai perusahaan merupakan hal penting diteliti karena nilai perusahaan mencerminkan pertumbuhan dan kinerja manajemen. Jika nilai perusahaan tinggi investor akan tertarik berinvestasi pada perusahaan tersebut. Harga pasar merupakan harga jual saham sebagai konsekuensi dari posisi tawar antara penjual dan pembeli saham sehingga nilai pasar menunjukan fluktuasi dari harga saham.

Nilai dari suatu perusahaan tidak hanya bergantung pada kemampuan menghasilkan arus kas tetapi juga bergantung pada karakteristik operasional dan keuangan perusahaan yang diambil alih. Beberapa alternative untuk menilai perusahaan diantaranya adalah: Price Book Value, PER ( Price Earning Ratio), Enterprise Value, Price Earning Ratio Method, Discounted Cashflow Approach, Nilai Apprasial dan Nilai Pasar Saham Ada beberapa faktor yang mempengaruhi Nilai Perusahaan yaitu: ukuran perusahaan, profitabilitas, pertumbuhan laba, likuiditas dan inflasi(Keown, 2008:849).

Beberapa hasil penelitian menyatakan bahwa :Tekanan eksternal tidak berpengaruh signifikan terhadap transparansi laporan keuangan(Davici, 2018). Tekanan eksternal tidak terdapat pengaruh dari tekanan eksternal yang proksikan dengan rasio leverage terhadap kecurangan laporan keuangan(ljudien, 2018).Kapitalisasi pasar berpengaruh terhadap nilai emiten(Rifqiawan ,2015). Nilai kapitalisasi pasar tidak berpengaruh (Agape, 2013). Tekanan dan Kapitalisasi berpengaruh secara signifikan secara simultan terhadap nilai perusahaan (Gultom et al, 2013).

Dalam jangka panjang, tujuan perusahaan adalah mengoptimalkan nilai perusahaan. Semakin tinggi nilai perusahaan menggambarkan semakin sejahtera pula pemiliknya. Nilai perusahaan akan tercermin dari harga pasar sahamnya. Nilai pasar perusahaan merupakan inovasi terpenting yang membantu para manajer untuk lebih memahami tujuan keuangan, dan dengan demikian membantu mereka mencapai tujuan yang telah ditetapkan.

Berdasarkan uraian di atas fenomena naik turunnya kinerja perusahaan dengan menggunakan metode Altman Z-Score, Nilai kapitalisasi pasar dan Current ratio (CR) pada nilai perusahaan dipengaruhi oleh tekanan keuangan dan kapitalisasi pasar. Oleh karena itu, maka penulis tertarik mengambil judul penelitian tentang "Pengaruh Tekanan Keuangan dan Kapitalisasi Pasar terhadap Nilai Perusahaan Studi Kasus pada Perusahaan Transportasi".

\section{METODE PENELITIAN}

Populasi yang digunakan dalam penelitian ini adalah perusahaan sub sektor transportasi yang sudah terdaftar di Bursa Efek Indonesia periode 2013-2018. Penelitian ini menggunakan metode purposive sampling dalam menentukan sampel. Adapun kriteria yang diterapkan peneliti dalam pemilihan sampel adalah sebagai berikut:

1. Merupakan perusahaan sub sektor transportasi yang terdaftar di BEI tahun $2013-2018$

2. Perusahaan transportasi yang berturut-turut menerbitkan laporan keuangan tahun 2013 $-2018$

3. Perusahaan transportasi yang terdaftar di BEI yang memiliki data lengkap yang dibutuhkan peneliti

Berdasarkan kriteria tersebut, peneliti telah menentukan bahwa terdapat 10 perusahaan sub sektor transportasi yang memenuhi kriteria tersebut. 10 perusahaan tersebut akan digunakan sebagai sampel penelitian dengan jumlah observasi sebanyak 60 data. 


\section{HASIL DAN PEMBAHASAN}

\section{Statistik Deskriptif}

Tabel 4.1

Hasil Pengujian Statistik Deskriptif

Descriptive Statistics

\begin{tabular}{|l|r|r|r|r|r|r|}
\hline & \multicolumn{1}{|c|}{ N } & Minimum & Maximum & \multicolumn{2}{|c|}{ Mean } & Std. Deviation \\
\cline { 2 - 7 } & Statistic & Statistic & Statistic & Statistic & $\begin{array}{c}\text { Std. } \\
\text { Error }\end{array}$ & \multicolumn{1}{c|}{ Statistic } \\
\hline Tekanan & 56 &,- 25 &, 66 &, 0371 &, 02338 &, 17497 \\
Keuangan & 56 & 13,53 & 29,33 & 24,3970 &, 53838 & 4,02886 \\
Kapitalisasi & 56 & 1,78 & 18,52 & 5,8011 &, 50972 & 3,81436 \\
Pasar & 56 & & & & & \\
Y & & & & & \\
Valid N & (listwise) & & & & & \\
\hline
\end{tabular}

Sumber: Hasil pengolah data pada SPSS23

Tabel 4.1 yang menyajikan statistik dari sampel penelitian yang menggambarkan nilai minimum, maximum, rata-rata dan standar deviasi masing-masing variabel.Nilai $\mathrm{N}$ menunjukan banyaknya data yang digunakan dalam penelitian ini yaitu lamanya periode tahun sesuai data yang termasuk kedalam kriteria.

\section{Uji Normalitas}

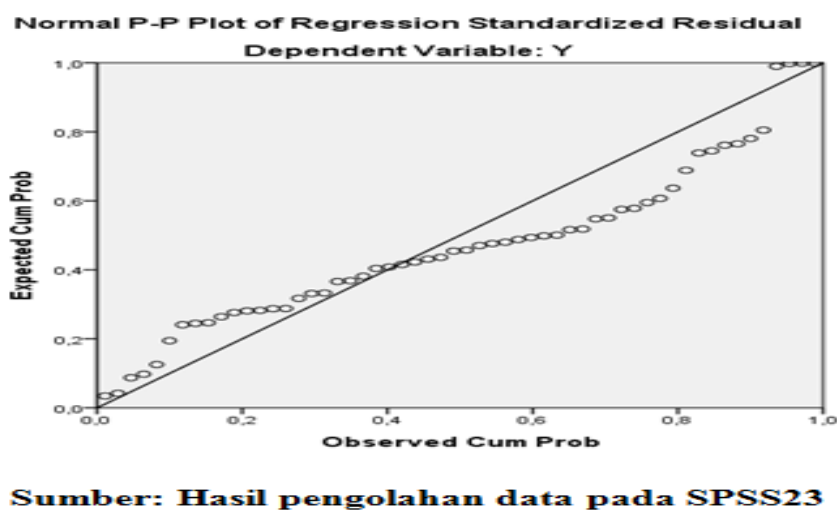

Gambar 4.1

Hasil Uji Normalitas

Hasil uji normalitas menunjukan titik menyebar disekitar garis diagonal dan mengikuti arah garis diagonal.Maka, model regresi memenuhi asumsi uji normalitas.

Tabel 4.2

Hasil Uji Normalitas

One-Sample Kolmogorov-Smirnov Test

\begin{tabular}{|ll|r|}
\hline & & $\begin{array}{r}\text { Unstandardized } \\
\text { Residual }\end{array}$ \\
\hline Normal Parameters & Mean & 56 \\
Most Extreme Differences & Std. Deviation &, 0000000 \\
& Absolute &, 06025495 \\
& Positive &, 060 \\
Test Statistic & Negative &,- 047 \\
Asymp. Sig. (2-tailed) & &, 060 \\
\hline
\end{tabular}

a. Test distribution is Normal.

b. Calculated from data.

Sumber: Hasil pengolahan data pada SPSS23 
Berdasarkan tabel 4.2 hasil uji normalitas diatas menunjukan nilai Asymp. Sig (2-tailed) sebesar 0,200 lebih besar dari 0,05 maka dapat disimpulkan bahwa data yang digunakan dalam penelitian ini data distribusi normal.

\section{Uji Multikolineralisitas}

Tabel 4.3

Hasil Uji Multikolineralisitas

\begin{tabular}{|ll|r|c|}
\hline \multicolumn{2}{|c|}{ Coefficients $^{\mathrm{a}}$} \\
\cline { 3 - 4 } Model & \multicolumn{2}{|c|}{ Collinearity Statistics } \\
\cline { 3 - 4 } 1 & (Constant) & & \multicolumn{1}{c|}{ VIF } \\
\cline { 2 - 4 } & Tekanan Keuangan &, 982 & 1,018 \\
& Kapitalisasi Pasar &, 982 & 1,018 \\
\hline
\end{tabular}

a. Dependent Variable: $Y$

Sumber: Hasil pengolahan data pada SPSS23

Berdasarkan tabel 4.3 hasil uji multikolineralisistas, dapat diketahui bahwa semua variabel independen, yaitu Tekanan Keuangan dan Kapitalisasi Pasar memiliki nilai tolarance lebih besar dari 0,10 dan nilai VIF lebih kecil dari 10. Artinya tidak terdapat multikolineralisitas, sehingga data baik digunakan.

Uji heteroskedastisitas

Scatterplot

Dependent Variable: $Y$

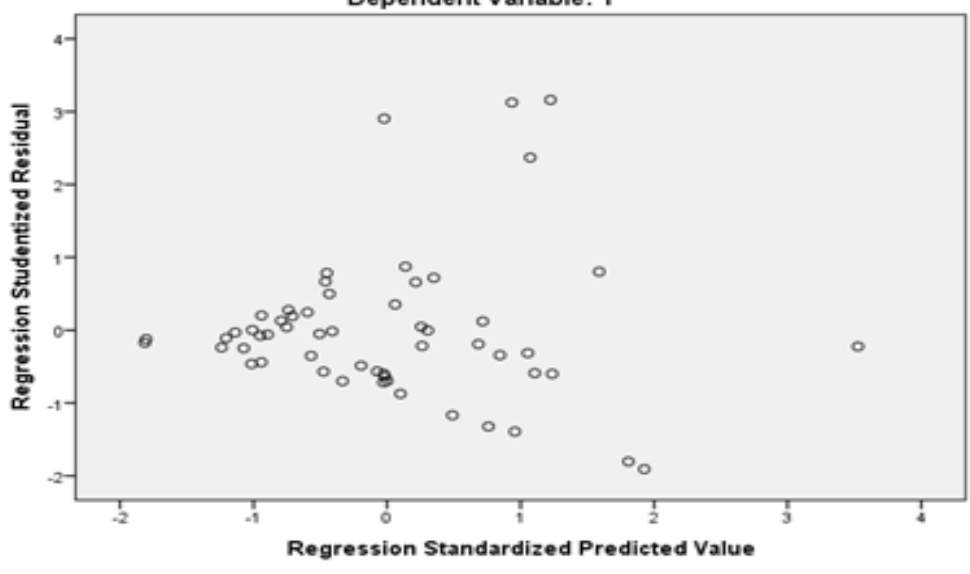

Sumber: Hasil pengolahan data pada SPSS23

Gambar 4.4

Uji Heteroskedastisitas

Berdasarkan gambar 4.2 terlihat data residual pada kedua model regresi menyebar baik diatas maupun dibawah titik 0 dan tidak membentuk pola tertentu. Dengan demikian model regresi yang diajukan dalam penelitian ini tidak terjadi gejala heteroskedastisitas. 


\section{Analisis Regresi Linier Berganda}

Tabel 4.4

Hasil Uji Analisis Regresi Berganda

Coefficients $^{\mathrm{a}}$

\begin{tabular}{|c|c|c|c|c|c|c|c|}
\hline & \multicolumn{2}{|c|}{$\begin{array}{c}\text { Unstandardized } \\
\text { Coefficients }\end{array}$} & $\begin{array}{c}\text { Standardized } \\
\text { Coefficients }\end{array}$ & & \multicolumn{2}{|c|}{ Collinearity Statistics } \\
\cline { 2 - 7 } \cline { 6 - 8 } Model & B & Error & Beta & T & Sig. & Tolerance & VIF \\
\hline (Constant) & 1,305 &, 386 & & 3,378 &, 001 & & \\
Tekanan Keuangan & 1,644 &, 361 &, 529 & 4,550 &, 000 &, 982 & 1,018 \\
Kapitalisasi Pasar &, 010 &, 016 &, 070 &, 606 &, 547 &, 982 & 1,018 \\
\hline
\end{tabular}

a. Dependent Variable: Nilai Pasar Perusahaan

Sumber: Hasil pengolahan data pada SPSS23

Berdasarkan tabel 4.4 diatas, maka dapat disusun persamaan regresinya:

$$
Y=a+b 1 X 1-b 2 X 2+e
$$

$\mathrm{Y}=1,305+1,644$ Tekanan Keuangan + 0,010 Kapitalisasi Pasar + e

Dari persamaan regresi yang telah disusun diatas, dapat diinterpretasikan sebagai berikut:

1. Nilai konstanta sebesar 1,305 menunjukan bahwa apabila variabel independen bernilai nol (0) atau ditiadakan, maka agresivitas Nilai Pasar Perusahaan adalah sebesar 1,305

2. Koefisien Tekanan Keuangan sebesar 1,644 menunjukan bahwa setiap penambahan Tekanan Keuangan sebesar satu satuan, maka akan di ikuti oleh kenaikan nilai agresitivitas Nilai Pasar Perusahaan sebesar 1,644

3. Koefisien Kapitalisasi Pasar sebesar 0,010 menunjukan bahwa setiap penambahan kapitalisasi pasar sebesar satu satuan, maka akan diikuti oleh penurunan agresitivitas Nilai Pasar Perusahaan sebesar 0,010

Uji T (Parsial)

Tabel 4.5

Hasil Pengujian Parsial (Uji T)

Coefficients $^{\mathrm{a}}$

\begin{tabular}{|c|c|c|c|c|c|c|c|}
\hline \multirow[b]{2}{*}{ Model } & \multicolumn{2}{|c|}{$\begin{array}{c}\text { Unstandardized } \\
\text { Coefficients } \\
\end{array}$} & \multirow{2}{*}{\begin{tabular}{|c|}
$\begin{array}{c}\text { Standardized } \\
\text { Coefficients }\end{array}$ \\
Beta \\
\end{tabular}} & \multirow[b]{2}{*}{$\mathrm{T}$} & \multirow[b]{2}{*}{ Sig. } & \multicolumn{2}{|c|}{ Collinearity Statistics } \\
\hline & $\mathrm{B}$ & $\begin{array}{l}\text { Std. } \\
\text { Error }\end{array}$ & & & & Tolerance & VIF \\
\hline 1 (Constant) & 4,337 & 2,793 & & 1,553 & ,126 & & \\
\hline Tekanan Keuangan & 10,777 & 2,612 & ,494 & 4,126 &, 000 & ,982 & 1,018 \\
\hline Kapitalisasi Pasar & 044 & 113 & 046 & 385 & 702 & 982 & 1,018 \\
\hline
\end{tabular}

a. Dependent Variable: $Y$

\section{Sumber: Hasil pengolahan data pada SPSS23}

Berdasarkan tabel 4.6 hasil pengujian uji parsial (uji statistik t) diperolah hasil sebagai

1. Pengujian hipotesis $(\mathrm{H} 1)$

Hasil pengujian tekanan keuangan didapat $\mathrm{t}_{\text {hitung }}$ sebesar 4,126 dan $\mathrm{t}_{\text {tabel }}$ pada signifikansi $0,005 / 2=0,025$. Jadi dapat diartikan nilai $t_{\text {hitung }}>t$ tabel sebesar $(4,126$ $>2,003$ ). Dan nilai signifikansi sebesar 0,00 yang menunjukan nilai signifikan lebih kecil dari 0,05 maka $\mathrm{H} 1$ diterima.

Kesimpulan yang diambil adalah tekanan keuangan secara parsial memiliki pengaruh yang signifikan terhadap nilai pasar perusahaan. Hasil penelitian ini tidak sejalan dengan hasil penelitian yang dilakukan oleh Davici (2018) yang 
menyatakan bahwa tekanan eksternal tidak berpengaruh terhadap transparansi laporan keuangan. Dan hasil penelitian ini juga tidak sejalan dengan ljudien (2018) yang menyatakan bahwa untuk tekanan eksternal yang diproksikan dengan rasio Leverage terhadap kecurangan laporan keuangan.

Hal ini membuktikan dalam penelitian ini, peneliti mengamati tekanan keuangan yang dilakukan setiap perusahaan dalam setiap tahunnya dan menemukan bahwa pengungkapan tekanan keuangan yang dilakukan oleh setiap perusahaan berbedabeda setiap tahunnya.

2. Pengujian hipotesis (H2)

Hasil pengujian kapitalisasi pasar didapat $t_{\text {hitung }}$ sebesar 0,385 dan $t_{\text {tabel }}$ pada signifikansi $0,005 / 2=0,025$. Jadi dapat diartikan nilai $t_{\text {hitung }}<t_{\text {tabel }}$ sebesar $(0,385$ $<2,003)$. Dan nilai signifikansi sebesar 0,702 maka H2 ditolak.

Kesimpulan yang diambil adalah variabel kapitalisasi pasar secara parsial tidak memiliki pengaruh signifikan terhadap nilai pasar perusahaan. Hasil penelitian ini sejalan dengan hasil peneiltian yang dilakukan oleh Devi Rusdian, Eva Misfah Bayuni dan Azib (2017) yang menyatakan bahwa kapitalisasi pasar berpengaruh terhadap nilai perusahaan. Hasil penelitian ini tidak sejalan dengan hasil penelitian yang dilakukan oleh Raden Arfan Rifqiawan (2015) yang menyatakan bahwa kapitalisasi pasar berpengaruh terhadap nilai emiten. Hasil penelitian ini juga tidak sejalan dengan hasil penelitian Juido, Kevin, et al.(2013) yang menyatakan bahwa belum berhasil membuktikan pola hubungan kapitalisasi pasar. Hasil penelitian ini juga tidak sejalan dengan hasil penelitian yang dilakukan oleh Agape (2013) yang menyatakan bahwa nilai kapitalisasi pasar tidak berpengaruhterhadap nilai perusahaan.

Hal ini membuktikan dalam penelitian ini, peneliti mengamati bahwa nilai kapitalisasi pasar yang ingin menanamkan modal yang memiliki nilai kapitalisasi pasar yang tinggi hendaknya lebih mempertimbangkan nilainya sehingga dapat terhindar dari kerugian akibat jatuhnya nilai perusahaan.

\section{Uji F (Simultan)}

Tabel 4.6

Pengujian Signifikansi Simultan (Uji F)

\begin{tabular}{|c|c|c|c|c|c|c|}
\hline \multicolumn{7}{|c|}{ ANOVA $^{a}$} \\
\hline \multicolumn{2}{|c|}{ Model } & $\begin{array}{l}\text { Sum of } \\
\text { Squares }\end{array}$ & df & $\begin{array}{c}\text { Mean } \\
\text { Square }\end{array}$ & $\mathrm{F}$ & Sig. \\
\hline \multirow[t]{3}{*}{1} & Regression & 202,144 & 2 & 101,072 & 8,957 &, $000^{\circ}$ \\
\hline & Residual & 598,071 & 53 & 11,284 & & \\
\hline & Total & 800,215 & 55 & & & \\
\hline
\end{tabular}

a. Dependent Variable: $Y$

b. Predictors: (Constant), Kapitalisasi Pasar, Tekanan Keuangan

\section{Sumber: Hasil pengolahan data pada SPSS23}

Dari hasil tabel 4.5 perhitungan yang diperoleh nilai $\mathrm{F}$ hitung sebesar 8,957 dengan signifikansi sebesar 0,000 lebih kecil dari 5\%.Selanjutnya, membandingkan $\mathrm{F}$ hitung dengan $\mathrm{F}$ tabel.Dimana jika $\mathrm{F}$ hitung $>\mathrm{F}$ tabel maka secara simultan variabel-variabel independen berpengaruh signifikan terhadap variabel dependen. Menggunakan $a=0,05$ diperoleh nilai $F$ tabel sebesar 2,77

Jadi, nilai $\mathrm{F}$ hituung sebesar 8,957 dan $\mathrm{F}$ tabel 2,77 artinya $\mathrm{F}$ hitung $>\mathrm{F}$ tabel $(8,957>$ 2,77 ) atau nilai signifikansi $0,000<0,05$ sehingga $\mathrm{H} 0$ ditolak dan Ha diterima. Dengan demikian semua variabel independen dalam penelitian ini yang berupa pengungkapan kapitalisasi pasar dan tekanan keuangan secara bersama-sama (simultan) mempunyai pengaruh yang signifikan terhadap nilai pasar perusahaan.

Hasil penelitian ini juga sejalan dengan hasil penelitian yang dilakukan Robinhot Gultom, Agustina dan Sri Widia Wijaya (2013) yang menyatakan kapitalisasi pasar dan tekanan keuangan berpengaruh secara signifikan terhadap nilai perusahaan. Hasil penelitian ini sejalan dengan hasil penelitian yang dilakukan oleh Ni Putu Yuni Pratiwi, Fridayana Yudiatmaja, I Wayan Suwendra (2016) yang menyatakan kapitalisasi pasar dan tekanan keuangan berpengaruh terhadap nilai perusahaan.

Dalam penelitian ini peneliti mengamati bahwa nilai perusahaan lebih cenderung menyukai pendanaan internal dan eksternal sehingga tekanan keuangan dan kapitalisasi pasar 
mempunyai pengaruh yang signifikan. Hal ini dimungkinkan karena peningkatan biaya bunga dan peningkatan biaya pajak dimana pendapatan perusahaan yang diperoleh tidak stabil disetiap tahunnya dan beban biaya yang dikeluarkan oleh perusahaan tetap yang dapat mengakibatkan pengaruh terhadap nilai pasar perusahaan.

\section{Pengujian Koefisien Determinasi $\left(\mathbf{R}^{2}\right)$}

Tabel 4.7

Hasil Analisis Koefisien Determinasi Model Summary ${ }^{\mathrm{b}}$

\begin{tabular}{|l|r|r|r|c|}
\hline Model & \multicolumn{1}{|c|}{$\mathrm{R}$} & R Square & \multicolumn{1}{c|}{$\begin{array}{l}\text { Adjusted } \mathrm{R} \\
\text { Square }\end{array}$} & $\begin{array}{l}\text { Std. Error of the } \\
\text { Estimate }\end{array}$ \\
\hline 1 &, $503^{\mathrm{a}}$ &, 253 &, 224 & 3,35922 \\
\hline
\end{tabular}

a. Predictors: (Constant), Kapitalisasi Pasar, Tekanan Keuangan

\section{b. Dependent Variable: $Y$}

\section{Sumber: Hasil pengolahan data pada SPSS23}

Dari tabel 4.7 diatas, dapat dilihat bahwa nilai $\mathrm{R}^{2}$ mencerminkan kemampuan variabel bebas menjelaskan variabel-variabel terikat. Berdasarkan pengolahan menggunakan software windows SPSS23 didapatkan nilai $\mathrm{R}^{2}$ adalah $22,4 \%$. Nilai ini menunjukan bahwa $22,4 \%$ dari variasi tekanan keuangan dan kapitalisasi pasar sedangkan sisanya sebesar $77,6 \%$ dijelaskan oleh faktor lain seperti: ukuran perusahaan, profitabilitas, pertumbuhan laba, likuiditas dan inflasi yang tidak dimasukan dalam model regresi.

\section{KESIMPULAN}

Dalam kesimpulan tidak boleh ada referensi. Kesimpulan berisi fakta yang didapatkan, cukup menjawab permasalahan atau tujuan penelitian (jangan merupakan pembahasan lagi); Nyatakan kemungkinan aplikasi, implikasi dan spekulasi yang sesuai. Jika diperlukan, berikan saran untuk penelitian selanjutnya. Nyatakan simpulan dalam kalimat berbentuk paragraf, bukan dalam bentuk numbering.

Penelitian ini bertujuan untuk mengetahui Pengaruh Tekanan Keuangan dan Kapitalisasi Pasar terhadap Nilai Pasar Perusahaan (Studi kasus Pada Perusahaan Transportasi Yang Terdaftar di Bursa Efek Indonesia Periode 2013-2018). Berdasarkan analisis data yang telah dilakukan maka peneliti akan memberikan beberapa kesimpulan sebagai yaitu, berdasarkan hasil uji t variabel Tekanan Keuangan dengan tingkat signifikansinya $0,00<0,005$, jadi secara variabel parsial pengungkapan Tekanan Keuangan berpengaruh terhadap Nilai Pasar Perusahaan dan sesuai dengan hipotesis pertama, berdasarkan hasil uji t variabel Kapitalisasi Pasar dengan tingkat signifikansinya 0,702 >0,005, jadi secara parsial variabel Kapitalisasi Pasar tidak berpengaruh terhadap Nilai Pasar Perusahaan dan tidak sesuai dengan hipotesis kedua dan berdasarkan hasil uji $f$ variabel Tekanan Keuangan dan Kapitalisasi Pasar terhadap Nilai Pasar Perusahan dengan tingkat signifikansinya $0,00<0,005$, jadi secara parsial variabel Tekanan Keuangan dan Kapitalisasi Pasar berpengaruh terhadap Nilai Pasar Perusahaan dan sesuai dengan hipotesis ketiga.

Saran terikat dengan keterbatasan penelitian yang sudah disebutkan sebelumnya, berikut adalah beberapa saran untuk penelitian selanjutnya yaitu bagi peneliti selanjutnya diharapkan untuk menambahkan variabel atau mengganti objek yang berbeda. bagi perusahaan transportasi yang terdaftar di Bursa Efek Indonesia diharapkan untuk memberikan data yang lengkap setiap tahunnya agar orang lain dapat dengan mudah mendapatkan data - data yang lengkap setiap perusahaannya bagi bidang akademis diharapkan untuk lebih memperbanyak data dan sumber agar peneliti lain dapat dengan mudah mendapatkan data yang di cari dan di inginkan nya.

\section{UCAPAN TERIMAKASIH}

Terima kasih kepada para Pimpinan dan rekan sejawat di Universitas Serang Raya yang telah mensupport terhadap penelitian ini. 


\section{REFERENCES}

[1] Ang, R. (1997). Buku Pintar Pasar Modal Indonesia. Jakarta: Mediasoft.

[2] Agape, P. (2013).Pengaruh Faktor Fundamental dan Nilai Kapitalisasi Pasar terhadap Return Saham.Sekolah Tinggi llmu Ekonomi Perbanas.

[3] Darsono \& Ashari.(2005). Pedoman Praktis Memahami Laporan Keuangan. Yogyakarta:Andi.

[4] Davici, N. (2018). Pengaruh Tekanan Eksternal, Komitmen Pimpinan dan Faktor Politik terhadap Transparansi Laporan Keuangan (Studi Empiris pada Organisasi Perangkat Daerah Kabupaten Agam).Jurnal Akuntansi 6.1.

[5] Gamayuni, R. R. (2011). Analisis Ketetapan Model Altham Sebagai Alat Untuk Memprediksi Kebangkrutan.Jurnal Akuntansi dan Keuangan Indonesia Volume 16 Nomor 2.

[6] Gultom R., \&Wijaya, A.S.W.(2013).Analisis Faktor-Faktor yang Mempengaruhi Nilai Perusahaan Farmasi Di Bursa Efek Indonesia.Jurnal Wira Ekonomi Mikroskil Vol. 3.

[7] Hasnawati, S. (2005).Dampak Set Peluang Investasi Terhadap Nilai Perusahaan Publik di Bursa Efek Indonesia.JAAl, Vol.9, No.2 Hal. 117-126.

[8] Hermawan, D. (2011). Pengaruh Tekananan Keuangan dan Kapitalisasi Pasar Terhadap Nilai Pasar Perusahaan.Ekspansi Jurnal Ekonomi, Keuangan, Perbankan dan Akuntansi Vol. 3. No. (1).

[9] Ijudien, D. (2018). Pengaruh Stabilitas Keuangan, Kondisi Industri, dan Tekanan Eksternal Terhadap Kecurangan Laporan Keuangan. Jurnal EkonomiVol. 2, (1) Hal. 82-97.

[10] Juido, Kevin, et al. ( 2013). Value At Risk Portofolio Saham Likuid: Kapitalisasi Besar dan Kapitalisasi Kecil. Jurnal Psikologi, Ekonomi, Sastra, Arsitektur dan Teknik Sipil Vol. 5.

[11] Keown, A. (2008). Manajemen Keuangan Edisi 10. Jakarta : PT. Macanan Jaya Cemerlang.

[12] Michalski, G. (2009). Inventory Management Optimization As a Part of Operational Risk Management. Economic Computation and Economic Cybernatics Studies and Research, pp. 213222.

[13] Noerirawan, M.R. (2012). Pengaruh Faktor Internal dan Eksternal perusahaan terhadap Nilai Perusahaan.Jurnal Akuntansi Vol.1 No.2, hal.4.

[14] Owolabi, A. (2012).Effect of Organizational Justice and Organizational Envoirement on Trun-Over Intention of Health Workers in Ekiti State, Nigeria. Research in World Economy Vol. 3 No. 1, 28-34.

[15] Pratiwi, N. P. Y., Yudiatmaja, F., \&Suwendra, I.W. (2016). Pengaruh Struktur Modal dan Ukuran Perusahaan terhadap Nilai Perusahaan Sektor Infrastruktur, Utilitas dan Transportasi Periode 2011 2014.Jurnal Vol.4.

[16] Rifqiawan, R.( 2015). Pengaruh Profitabilitas dan Kapitalisasi Pasar Terhadap Nilai Emiten Jakarta Islamic Index.Jurnal Vol. VI.

[17] Rusdian, D., Bayuni, E. M., \& Azib.(2017). Pengaruh Kapitalisasi Pasar terhadap Nilai Perusahaan dengan Menggunakan Metode Tobin's Q.Jurnal Prosiding Hukum Ekonomi Syariah 3.2: 522 - 528.

[18] Sartono, A. (2010). Manajemen Keuangan Teori dan Aplikasi. Yogyakarta: BPFE. 